\title{
Reproductive Biology and Early Development of Two Species of Sleeper, Eleotris acanthopoma and Eleotris fusca (Teleostei: Eleotridae) ${ }^{1}$
}

\author{
Ken Maeda, ${ }^{2}$ Nozomi Yamasaki, ${ }^{2}$ Masashi Kondo, ${ }^{2}$ and Katsunori Tachibara ${ }^{3,4}$
}

\begin{abstract}
Reproductive biology and early development of two species of sleepers, Eleotris acanthopoma Bleeker, 1853, and E. fusca (Forster, 1801), were investigated in streams on Okinawa Island in southern Japan. Gonadal examination and morphology of the genital papillae indicated that E. acanthopoma matured at a smaller body size (ca. $28 \mathrm{~mm}$ in standard length) than E. fusca (ca. 50 $\mathrm{mm}$ ). Mature ovaries were composed of oocytes that could be categorized into two size classes. Larger females of both species had several hundred thousand developed oocytes in the larger size class and may spawn them at one or several consecutive spawning events. Egg masses of both species were found in habitats typically occupied by adults and were deposited, often sparsely, on the underside of objects. Form of the egg masses and morphology of eggs and newly hatched larvae of both species were almost identical. Eggs were a nearly spherical pyriform in shape, with the widest diameters measuring approximately $0.4 \mathrm{~mm}$. Newly hatched larvae were very small (1.0-1.4 $\mathrm{mm}$ in notochord length) and undeveloped. The mouth opened and the eyes became pigmented 3 days after hatching, and all of their yolk was consumed 4 days after hatching. Reproductive strategies of both species were characterized by high fecundity through production of small eggs and small newly hatched larvae, with high fecundity likely to mitigate the presumed increased risk associated with widespread larval dispersal.
\end{abstract}

Fishes of THE genus Eleotris have a global distribution and primarily inhabit estuaries and freshwater streams in both tropical and subtropical regions (Pezold and Cage 2002). Eleotris acanthopoma Bleeker, 1853, and E. fusca (Forster, 1801) are common species that have different distribution patterns with-

${ }^{1}$ This study was partially supported by the 21 st Century Center of Excellence (COE) Program of the University of the Ryukyus. Manuscript accepted $31 \mathrm{Au}-$ gust 2007.

${ }^{2}$ Graduate School of Engineering and Science, University of the Ryukyus, 1 Senbaru, Nishihara-cho, Nakagami-gun, Okinawa 903-0213, Japan.

3 Laboratory of Fisheries Biology and Coral Reef Studies, Faculty of Science, University of the Ryukyus, 1 Senbaru, Nishihara-cho, Nakagami-gun, Okinawa 903-0213, Japan (e-mail: ktachiha@sci.u-ryukyu.ac.jp).

${ }^{4}$ Corresponding author (e-mail: ktachiha@sci .u-ryukyu.ac.jp).

Pacific Science (2008), vol. 62, no. 3:327-340

(C) 2008 by University of Hawai'i Press

All rights reserved in the streams on Okinawa Island in the Ryukyu Archipelago of Japan. Eleotris acanthopoma is distributed from brackish-water areas to the lower reaches of freshwater areas, and E. fusca is distributed primarily in freshwater (Maeda and Tachihara 2004, 2006). Both species spend their pelagic larval stage in the sea before recruiting and settling in streams (Maeda and Tachihara 2005). Thus, E. fusca is considered a typical amphidromous fish, migrating between freshwater streams and the sea. The migration pattern of E. acanthopoma is similar to that of $E$. fusca except that the adults of $E$. acanthopoma are not restricted to freshwater environments.

The duration of the pelagic larval stage (2-4 months) is estimated to be relatively longer than in typical coastal marine gobies and some other amphidromous gobies (Maeda et al. 2007). It has been suggested that a portion of Eleotris pelagic larvae may be carried far away from their natal island by the Kuroshio Current, a strong current running along the Ryukyu Archipelago, where- 
after they recruit into streams on distant islands (Maeda et al. 2007). This scenario presupposes a great capacity for Eleotris larval dispersal.

Amphidromous gobioid fishes are often dominant species in isolated insular streams (Fitzsimons et al. 2002, Keith 2003, Keith et al. 2006), and the dispersal of pelagic larvae has been discussed extensively in an attempt to understand their distribution and population structure (Fitzsimons et al. 1990, Zink et al. 1996, Chubb et al. 1998, Keith et al. 2005, Watanabe et al. 2006). However, fundamental data on their life history are currently insufficient to understand their biogeography.

The reproductive biology of some sicydiine gobies, typical amphidromous fishes, has been studied intensively; they spawn very small eggs and are highly fecund (Manacop 1953, Dôtu and Mito 1955, Kinzie 1993, Ha and Kinzie 1996, Yamasaki and Tachihara 2006, 2007). Although the genus Eleotris is not closely related to the Sicydiinae (Gobiidae), several Eleotris species are also widely distributed among tropical and subtropical insular streams and, together with the sicydiine gobies, have colonized isolated oceanic islands such as Hawai'i (Yamamoto and Tagawa 2000) and French Polynesia (Marquet and Galzin 1992). With the exception of the temperate species Eleotris oxycephala (Dôtu and Fujita 1959, Matsuo and Takahama 2001, Dotsu et al. 2004), data on the reproductive biology of Eleotris are sparse.

In our study, size at first maturation and fecundity of E. acanthopoma and E. fusca were estimated based on analysis of adults collected on Okinawa Island. In addition, the spawning habits of these species were investigated in the field, and the morphology of the eggs and larvae were described under captive rearing conditions.

\section{MATERIALS AND METHODS}

Eleotris acanthopoma $(n=279)$ and E. fusca $(n=177)$ were collected using hand nets from 17 streams $\left(26^{\circ} 06-50^{\prime} \mathrm{N}, 127^{\circ} 40^{\prime}-\right.$ $\left.128^{\circ} 18^{\prime} \mathrm{E}\right)$ on Okinawa Island during the spawning season of 1997 (May-December [see Maeda et al. 2007]). The fishes were brought to the laboratory after fixation in $10 \%$ formalin and the standard lengths (SL) and body weights were measured. Gonads were dissected from each fish, weighed, and preserved in $10 \%$ buffered formalin. Sexes were distinguished by the morphology of the genital papilla and the gonads. The gonadosomatic index $(\mathrm{GSI}=$ gonad weight/body weight $\times 100)$ was calculated for all specimens. Body size at first maturation for $E$. acanthopoma and E. fusca was determined based on the relationship between SL and GSI.

A sample of oocytes was removed from the central portion of the ovaries of mature $E$. acanthopoma $(n=7 ; 28.8-68.7 \mathrm{~mm} \mathrm{SL})$ and E. fusca $(n=6 ; 67.2-109.0 \mathrm{~mm} \mathrm{SL})$. The diameters of 300 oocytes were measured on the longest axis using a profile projector and a caliper.

Thin sections of gonadal tissue $(8 \mu \mathrm{m})$ were prepared from the female specimens (E. acanthopoma, $n=14$; E. fusca, $n=12$ ) collected in October 1997 and were stained with Mayer's hematoxylin and eosin to examine the development of the oocytes.

To estimate fecundity, 10 samples of oocyte masses were removed from the ovaries of E. acanthopoma $(n=24)$ and $E$. fusca $(n=20)$. The number of oocytes identified as having developed past the late yolk stage (the widest diameter $>0.2 \mathrm{~mm}$ [see Results]) was counted and standardized by weight for the entire ovary. Correlation between standard length and number of developed oocytes within the ovary was plotted and the regression curves were obtained with power regression analysis.

Searches were conducted for egg masses belonging to E. acanthopoma and E. fusca in Yona Stream, Teima Stream, and Oh-ura Stream on northern Okinawa Island from 2004 to 2006. For each egg mass, we recorded the location, water temperature, water depth, and the characteristics of the object to which it was attached. The surface area of the entire side of the object to which the eggs were attached and the area of attachment were recorded by tracing on a transparent plastic sheet or by photograph. Fish in the vi- 

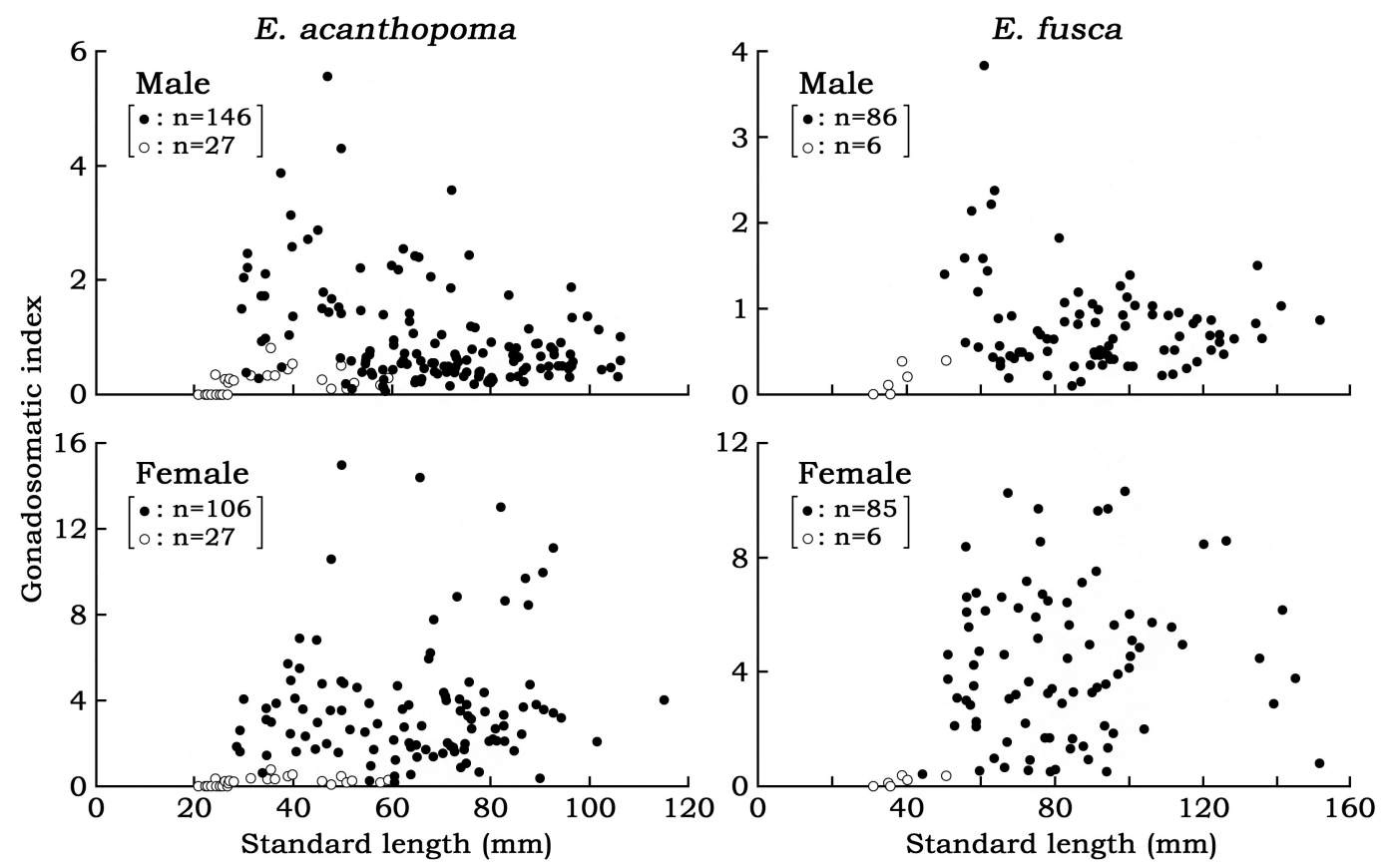

FIGURE 1. Relationship between standard length and gonadosomatic index of Eleotris acanthopoma and E. fusca, collected from streams on Okinawa Island from May to December 1997. Solid circles indicate males (above) and females (below); open circles indicate individuals whose sex could not be determined by morphology of genital papilla and the gonad.

cinity of the egg mass were captured using hand nets or by covering the object with a cast net. If the parent fish could not be captured or positively identified to species by observation, the data were not used for this study. Captured fish were identified to species, sexed using the morphology of the genital papilla, and their SL was measured. Egg samples were collected and fixed in 3\% formalin, and the vertical and horizontal diameters of 10 eggs per egg mass were measured under a microscope with an ocular micrometer.

An egg mass of E. acanthopoma, collected from Teima Stream at 1410 hours on 4 July 2005, and an egg mass of E. fusca, collected from Yona Stream at 1345 hours on 25 July 2005 , were brought to the laboratory and reared to investigate larval morphology. Most of the eggs from both species had already hatched at the time observations were conducted after their arrival at the laboratory on the evening of the day of collection. After hatching, E. acanthopoma larvae were reared in a plastic tank containing 25 liters water (salinity $=17-18 \mathrm{ppt} ; 25-28^{\circ} \mathrm{C}$ ), and $E$. fusca larvae were reared in a plastic tank containing 60 liters water (salinity $=17 \mathrm{ppt} ; 28^{\circ} \mathrm{C}$ ). Larval descriptions were based on samples collected from the tanks each evening until the larval yolk had been completely consumed. The eggs and larvae were sketched by observing them under a microscope. The notochord length (NL), total length, and yolk-sac diameters of 10 larvae per sample collection were measured using an ocular micrometer.

\section{RESULTS}

\section{Observation of Gonads}

The sex of Eleotris acanthopoma individuals smaller than $28 \mathrm{~mm}$ SL could not be distinguished by observations of genital papilla morphology or the gonad surface, and their GSI values were less than 0.4 . Once speci- 


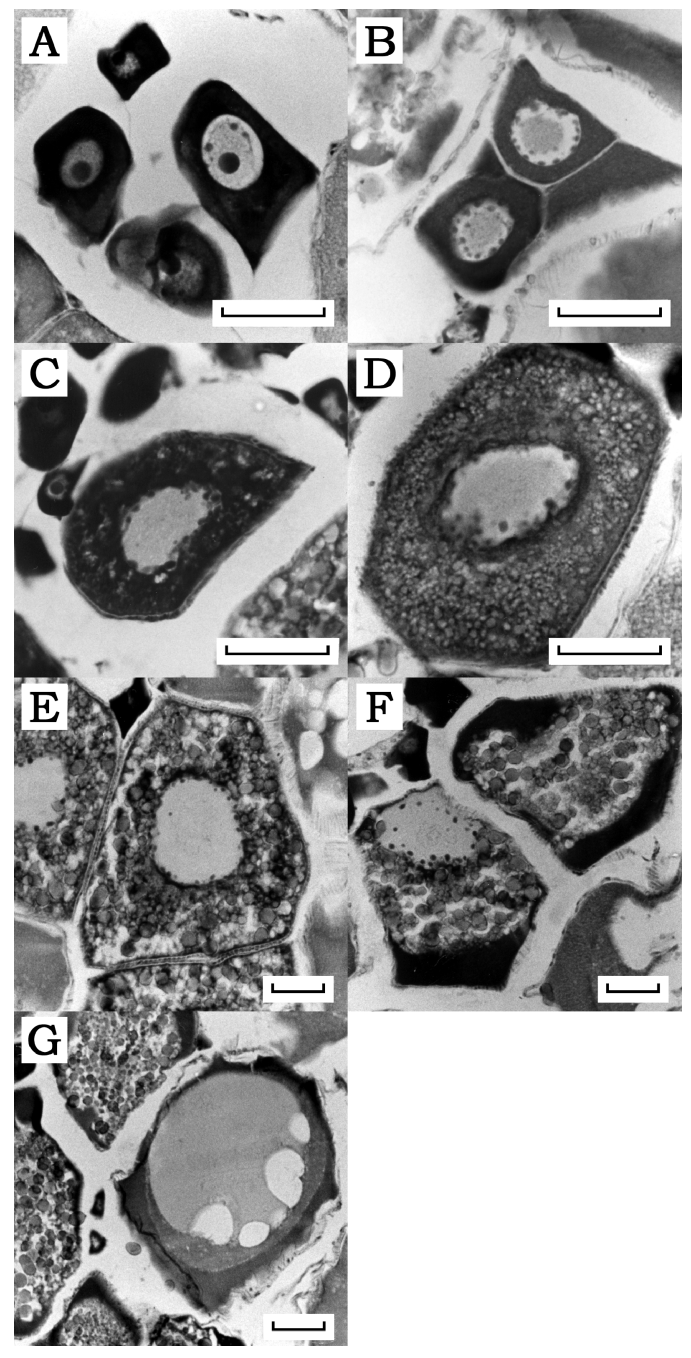

Figure 2. Oocyte development in Eleotris acanthopoma. $A$, early perinucleolus stage; $B$, late perinucleolus stage; $C$, oil globule stage; $D$, early yolk stage; $E$, late yolk stage; $F$, migratory nucleus stage; $G$, ripe stage. Scale bars $=50$ $\mu \mathrm{m}$.

mens exceeded $28 \mathrm{~mm}$ SL, sexual dimorphism of the genital papilla became apparent and GSI increased (Figure 1). The smallest $E$. fusca specimen with a distinctive female genital papilla was $44 \mathrm{~mm}$ SL, but its gonads were still relatively small $(\mathrm{GSI}=0.4)$ and were composed of only small undeveloped oocytes. The GSI of both sexes increased when the SL reached approximately $50 \mathrm{~mm}$ (Figure 1).

Oocytes of E. acanthopoma and E. fusca

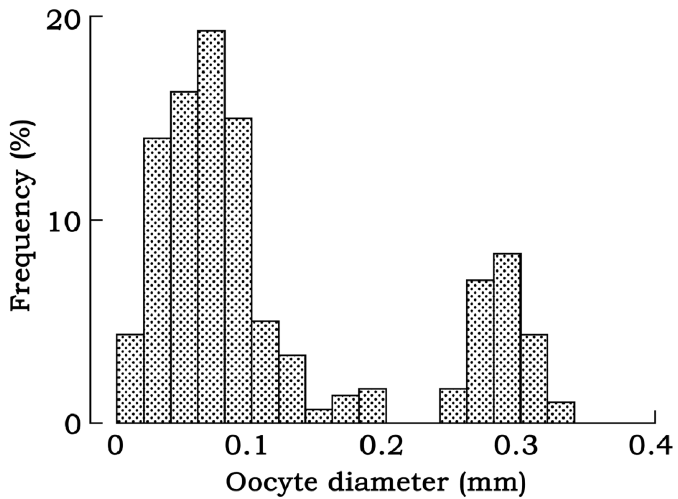

Figure 3. Oocyte diameter composition $(n=300)$ of Eleotris fusca (102 mm SL, GSI = 4.9) collected in June 1997, showing typical composition (two size classes of oocytes) for E. acanthopoma and E. fusca adults.

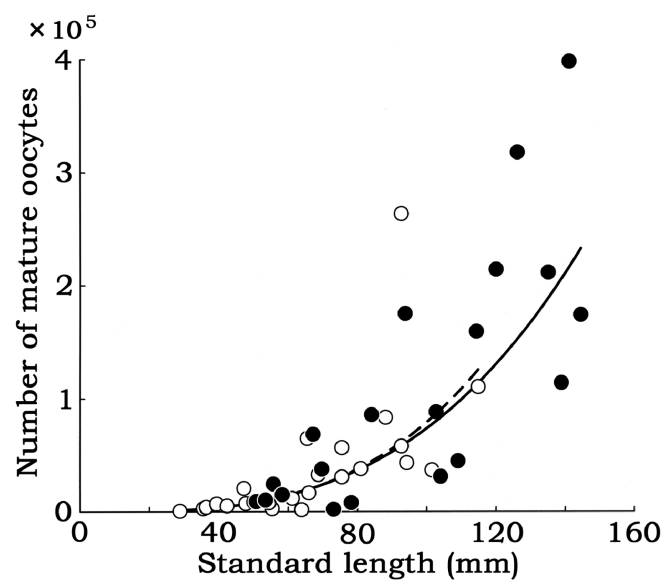

Figure 4. Correlation between standard length and number of developed oocytes $(>0.2 \mathrm{~mm})$ within the ovary of Eleotris acanthopoma (open circles and broken line, $\left.n=24, Y=0.018 X^{3.320} ; R=0.835\right)$ and $E$. fusca (solid circles and line, $n=20, Y=0.042 X^{3.125} ; R=$ 0.771 ) collected from streams on Okinawa Island.

could be classified into the following seven developmental stages: (1) early perinucleolus stage (Figure $2 A$; diameters along the longest axis $=32-68 \mu \mathrm{m}$ for $E$. acanthopoma and 26$72 \mu \mathrm{m}$ for $E$. fusca; this order of measurement for the two species is consistent throughout following descriptions): the cytoplasm, deeply stained with hematoxylin, surrounded a nucleus that contained plural nucleoli, one of which was particularly larger than the rest; (2) late perinucleolus stage (Figure 2B; 40-100 
$\mu \mathrm{m}$ and $46-94 \mu \mathrm{m})$ : the strong staining of cytoplasm with hematoxylin had decreased in intensity and all nucleoli were uniformly small and arranged at the margin of the nucleus; (3) oil globule stage (Figure 2C; $74-138 \mu \mathrm{m}$ and $80-140 \mu \mathrm{m}$ ): transparent oil globules appeared within the cytoplasm and the nucleoli became larger ellipses; (4) early yolk stage (Figure 2D; 126-166 $\mu \mathrm{m}$ and 130-170 $\mu \mathrm{m}$ ): small yolk globules stained with eosin appeared and oil globules became somewhat larger; (5) late yolk stage (Figure $2 E ; 140-255 \mu \mathrm{m}$ and $140-270 \mu \mathrm{m})$ : diameters often exceeded $0.2 \mathrm{~mm}$, yolk globules became larger, and oil globules increased in size, coalesced with others, and occupied the gaps between the yolk globules; (6) migratory nucleus stage (Figure $2 F ; 194-250 \mu \mathrm{m}$ and $180-240 \mu \mathrm{m})$ : the nucleus had moved to the margin of the oocyte and a thick cortical cytoplasm stained with hematoxylin was formed; (7) ripe stage (Figure 2G; 200-330 $\mu \mathrm{m}$, observed only for $E$. acanthopoma): the nucleus disappeared, yolk globules coalesced to form one large yolk, and the oil globules also coalesced into a few large globules.
All ovaries for which the oocyte diameters were measured contained two size classes of oocytes (Figure 3). The smaller size class was composed mainly of oocytes smaller than 0.1 $\mathrm{mm}$, and the other was composed mainly of oocytes larger than $0.2 \mathrm{~mm}$ (i.e., developed oocytes past the late yolk stage).

The number of oocytes of the larger size class (oocytes $>0.2 \mathrm{~mm}$ ) in 24 E. acanthopoma females (28.8-114.9 mm SL) ranged from 600 to 263,600 , whereas in 20 E. fusca females (50.8-144.5 mm SL) 2,200 to 398,200 developed oocytes were observed (Figure 4).

\section{Spawning Habit}

Sixteen E. acanthopoma egg masses were found in the streams on Okinawa Island, 11 located in the upper reaches of brackishwater areas, and five found in the lower reaches of freshwater areas. Two egg masses from $E$. fusca were found in the lower reaches of freshwater areas (Table 1). In freshwater areas, both species spawn in riffles and pools with gentle flow (17-60 cm depth). In brackish-water areas at low tide, egg masses

TABLE 1

Environmental Characteristics of the Area around Egg Masses of Eleotris acanthopoma and E. fusca in Teima, Yona, and Oh-ura Streams, Okinawa Island

\begin{tabular}{|c|c|c|c|c|c|c|c|c|c|}
\hline Date & Stream & $\begin{array}{c}\text { Brackish or } \\
\text { Freshwater } \\
\text { Area }\end{array}$ & $\begin{array}{l}\text { Water } \\
\text { Temp. } \\
\left({ }^{\circ} \mathrm{C}\right)\end{array}$ & $\begin{array}{l}\text { Water } \\
\text { Depth } \\
(\mathrm{cm})\end{array}$ & $\begin{array}{c}\text { Egg- } \\
\text { Deposited } \\
\text { Object }\end{array}$ & $\begin{array}{l}\text { Underside } \\
\text { of Object } \\
\left(\mathrm{cm}^{2}\right)\end{array}$ & $\begin{array}{l}\text { Egg } \\
\text { Mass } \\
\left(\mathrm{cm}^{2}\right)\end{array}$ & $\begin{array}{c}\text { SL of } \\
\text { Parent } \\
(\mathrm{mm})\end{array}$ & $\begin{array}{c}\text { No. of } \\
\text { Egggs }\end{array}$ \\
\hline \multicolumn{10}{|c|}{ Eleotris acanthopoma } \\
\hline 31 July 2004 & Teima & Brackish & 32.5 & 5 & Stone & 140 & 33 & 66 & 10,500 \\
\hline 31 July 2004 & Teima & Brackish & 30.8 & 8 & Stone & 289 & 113 & 69 & 21,400 \\
\hline 31 July 2004 & Teima & Fresh & 27.0 & 60 & Stone & 227 & 30 & 66 & 13,100 \\
\hline 4 July 2005 & Teima & Brackish & 32.5 & 6 & Plant pot & 160 & 49 & 48 & - \\
\hline 4 July 2005 & Teima & Brackish & 29.6 & 2 & Stone & 42 & 3 & 32 & - \\
\hline 9 July 2005 & Yona & Fresh & 26.0 & 30 & Stone & 221 & 22 & 57 & - \\
\hline 9 July 2005 & Yona & Fresh & 25.8 & 70 & Stone & 450 & 62 & 80 & - \\
\hline 25 July 2005 & Yona & Fresh & 24.6 & 25 & Stone & 350 & 81 & 88 & - \\
\hline 8 Aug. 2005 & Teima & Brackish & 31.0 & 7 & Stone & 162 & 61 & 48 & - \\
\hline 15 Aug. 2005 & Yona & Fresh & 27.0 & 17 & Stone & 875 & 98 & 90 & - \\
\hline 26 Aug. 2006 & Oh-ura & Brackish & 30.3 & 9 & Stone & 170 & 40 & 68 & 3,000 \\
\hline 26 Aug. 2006 & Oh-ura & Brackish & 33.0 & 9 & Stone & 94 & 16 & 53 & 2,200 \\
\hline 5 Sept. 2006 & Oh-ura & Brackish & 26.0 & 19 & Stone & 77 & 21 & 56 & 7,600 \\
\hline 5 Sept. 2006 & Oh-ura & Brackish & 25.8 & 10 & Stone & 590 & 27 & 59 & 10,600 \\
\hline 5 Sept. 2006 & Oh-ura & Brackish & 26.5 & 12 & Steel plate & 343 & 95 & 54 & 63,500 \\
\hline $\begin{array}{l}21 \text { Sept. } 2006 \\
\text { Eleotris fusca }\end{array}$ & Oh-ura & Brackish & 27.0 & 7 & Pottery dish & 38 & 6 & 30 & 1,500 \\
\hline \multicolumn{10}{|l|}{ Eleotris fusca } \\
\hline 12 June 2004 & Yona & Fresh & 17.0 & 50 & Stone & 300 & 55 & 98 & 33,600 \\
\hline 25 July 2005 & Yona & Fresh & 25.0 & 18 & Stone & 1,350 & 67 & 106 & - \\
\hline
\end{tabular}




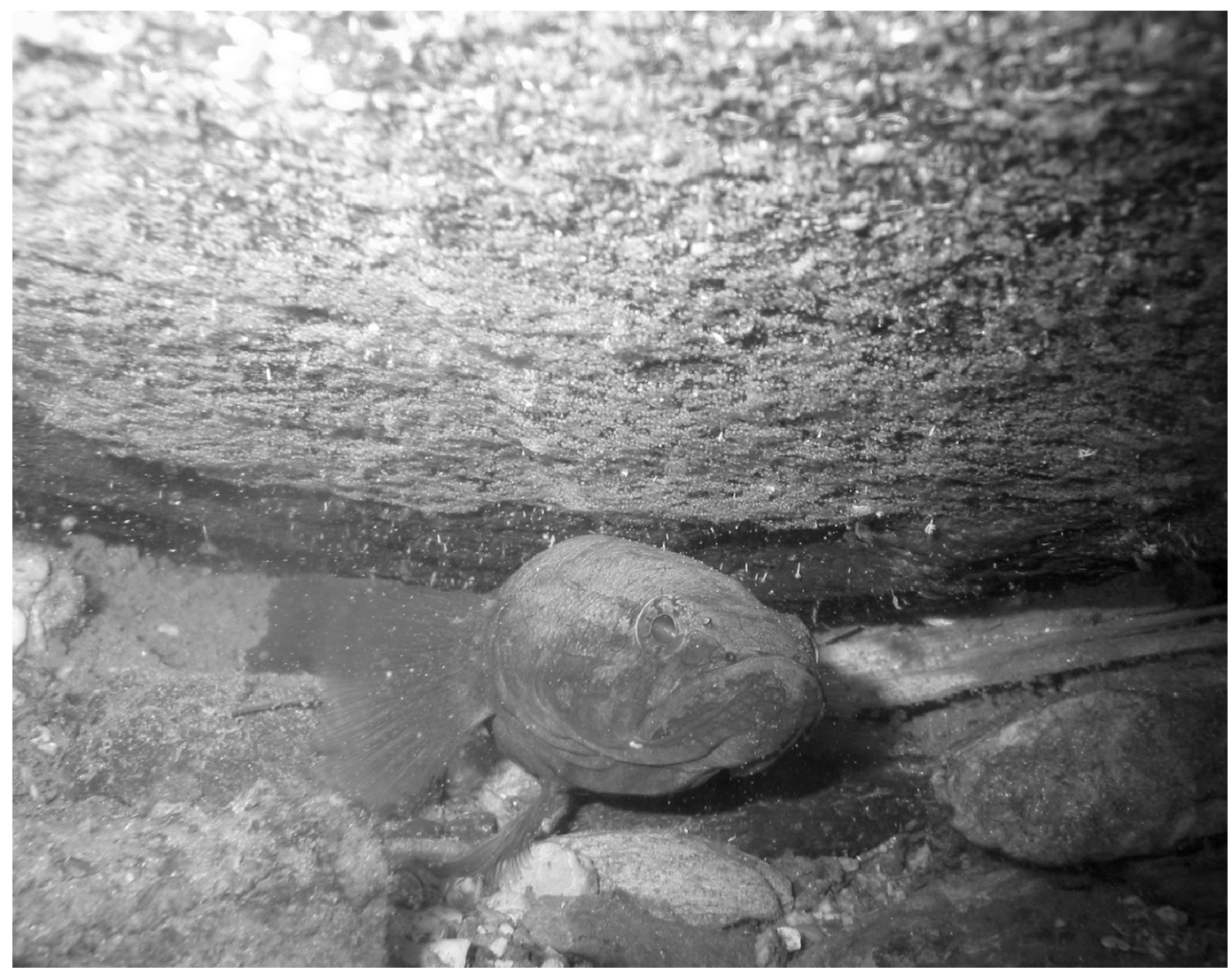

FIGURE 5. Adult Eleotris acanthopoma caring for an egg mass deposited on the underside of a stone in a freshwater area of Oh-ura Stream on Okinawa Island in September 2004.

of E. acanthopoma were found in riffles and pools with gentle flow as well as in shallows near the shore where the temperature often increased markedly (up to $33^{\circ} \mathrm{C}$ ). Egg masses were never exposed to the air (water depths at low tide $2-19 \mathrm{~cm})$.

All of the egg masses from both species were deposited on the underside of objects (Figure 5). Although most of these objects were natural stones on the streambed (area of the egg-deposited side 42-1,350 $\mathrm{cm}^{2}$ ), some artificial objects also were used by $E$. acanthopoma, including a plant pot fragment, a pottery dish, and a corrugated steel plate (38-343 $\mathrm{cm}^{2}$ [Table 1]). Solitary male fish, thought to be providing parental care, were usually found beneath the objects to which egg masses were attached (Table 1, Figure
5). The SL of these males ranged from 30$90 \mathrm{~mm}$ for E. acanthopoma and 98-106 mm for $E$. fusca.

Areas occupied by egg masses ranged between 3 and $113 \mathrm{~cm}^{2}$ for E. acanthopoma and 55 and $67 \mathrm{~cm}^{2}$ for E. fusca. Egg masses were usually deposited somewhat sparsely and in such a way that they had intricate groovelike gaps (Figure 6). Each egg mass was considered to be composed of a single clutch because of the uniformity of egg development and the appearance of the egg mass, which showed sparser egg distribution at its margin. The number of eggs within an egg mass could not be accurately determined due to difficulties in observing and handling the mass because of the sparse distribution of the eggs, variability of the density within an egg mass, 


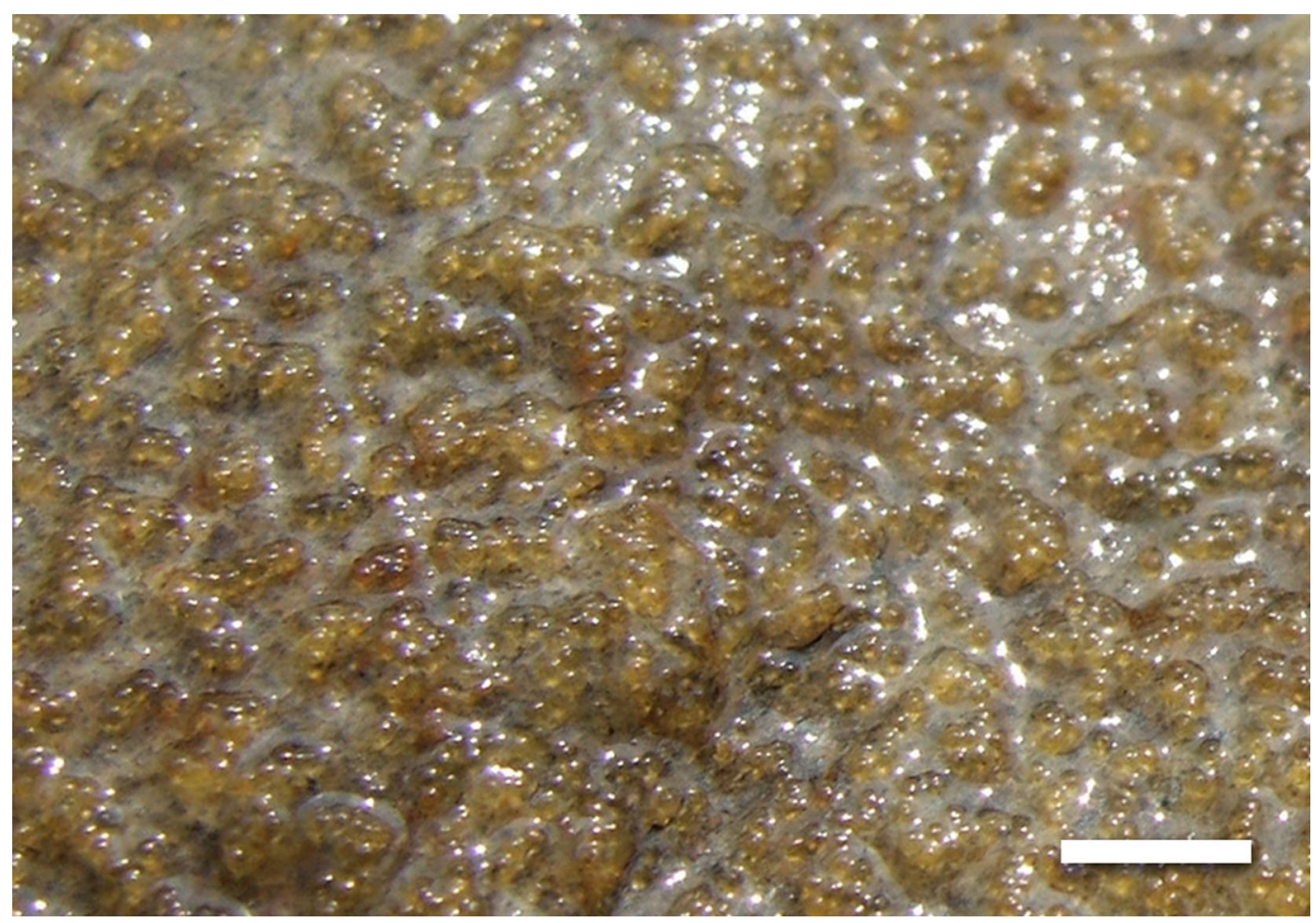

FiguRE 6. Magnified picture of the center of an Eleotris acanthopoma egg mass deposited on the underside of a stone, showing the typical arrangement of E. acanthopoma and E. fusca eggs. Scale bar $=3 \mathrm{~mm}$.

and the minute size of the eggs. However, cursory attempts at estimating the egg numbers by standardization from subsamples indicated that they numbered from 1,500 to 63,500 eggs for $E$. acanthopoma $(n=9)$ and approximately 33,600 eggs for E. fusca $(n=1)($ Table 1$)$.

\section{Early Development}

Eggs of both E. acanthopoma and E. fusca were nearly spherical, with a protuberance at the micropylar end where the adhesive filaments were attached (Figure 7). In E. acanthopoma, mean vertical diameters for 10 eggs from each of the 12 egg masses, measured with the micropyle located at the top (a in Figure 7), ranged between 0.35 and $0.43 \mathrm{~mm}$ (mean $=0.38 \mathrm{~mm} ; n=12$ egg masses), and mean horizontal diameters (b in Figure 7) ranged between 0.31 and $0.37 \mathrm{~mm}$ (mean $=$ $0.34 \mathrm{~mm} ; n=12$ egg masses). In E. fusca, the mean vertical and horizontal measurements for 10 eggs from each of the two egg masses were 0.38 and $0.39 \mathrm{~mm}$ (vertical) and 0.34 and $0.35 \mathrm{~mm}$ (horizontal).

The larval morphologies of the two species were also very similar. Newly hatched larvae (Figure $8 A-a, B-a$ ) of $E$. acanthopoma were $1.26-1.35 \mathrm{~mm} \mathrm{NL}$ and those of E. fusca were 1.02-1.09 mm NL (Table 2). Larvae of both species had large yolk sacs (E. acanthopoma, 0.31-0.37 $\mathrm{mm}$ in diameter; E. fusca, $0.26-0.29 \mathrm{~mm}$ ) (Table 2). The mouths of newly hatched larvae from both species had not yet developed, and lenses had formed, but the eyes were unpigmented. Melanophores appeared on the tip of the snout, above the eyes, on the anterior and posterior margins of the yolk sac, on the posterior half 


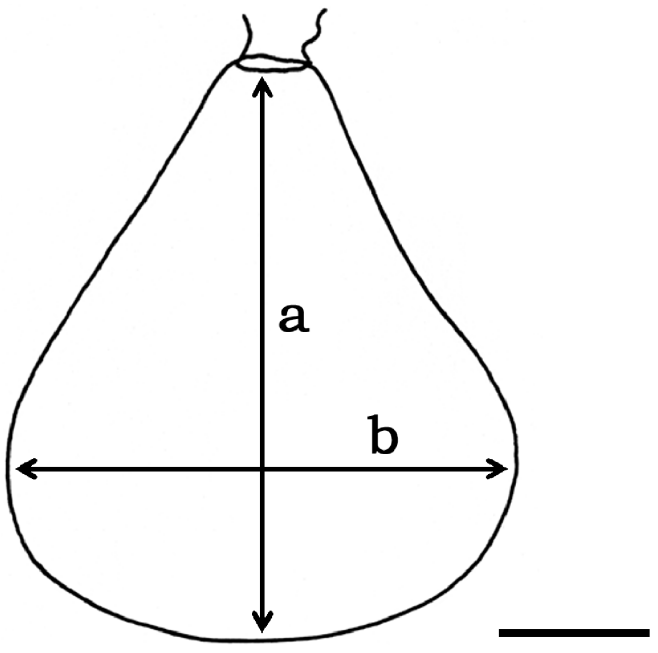

Figure 7. Schematic representation of Eleotris acanthopoma and E. fusca egg capsule shape. a and b represent vertical and horizontal diameters, respectively, measured in this study. Scale bar $=0.1 \mathrm{~mm}$.

\section{E. acanthopoma}

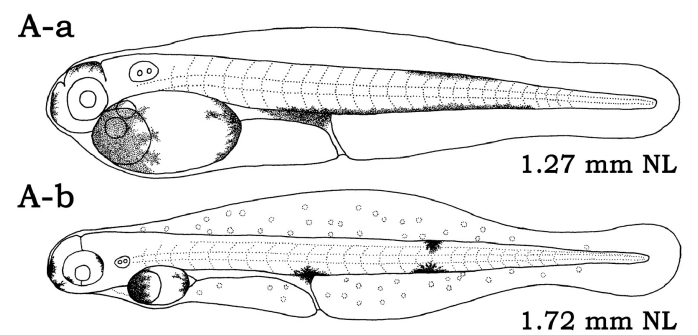

A-C

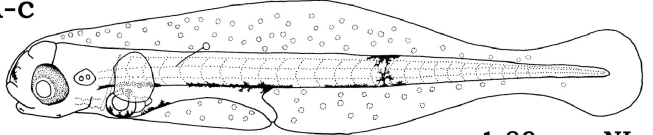

A-d

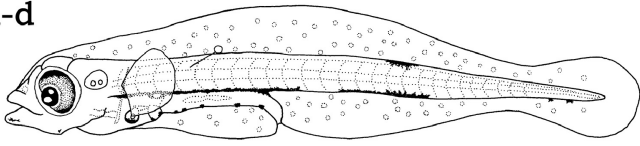

A-e

$1.83 \mathrm{~mm} \mathrm{NL}$

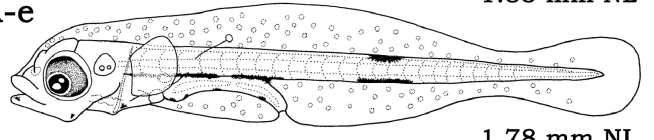

$1.78 \mathrm{~mm} \mathrm{NL}$ of the gut, ventrally on the posterior half of the trunk, ventrally on the anterior two-thirds of the tail, and dorsally on the midtail. Xanthophores were also associated with all melanophores.

One day after hatching (Figure $8 A-b, B-b$ ), the larvae exhibited marked growth and increased in size to $1.58-1.77 \mathrm{~mm}$ NL for $E$. acanthopoma and $1.70-1.76 \mathrm{~mm} \mathrm{NL}$ for $E$. fusca (Table 2). The yolk sac of both species decreased in size, and numerous granulated structures appeared on the body surface. Parts of the eye margin became pigmented and the melanophores and xanthophores above the eyes disappeared. The ventral melanophores, located above the anus and the midtail, became reduced. A dorsal melanophore was located on the midtail opposite a ventral one. Several $E$. fusca also had a ventral melanophore on the midtrunk without a xanthophore; however, because the occurrence of the melanophore varied between individu-

FigURE 8. Larval development in Eleotris acanthopoma and $E$. fusca: $A-a, B$ - $a$, immediately after hatching; $A-b, B-b, 1$ day after hatching; $A-c, B-c, 2$ days after hatching; $A-d, B-d, 3$ days after hatching; $A-e, B-e, 4$ days after hatching. 
TABLE 2

Notochord Length, Total Length, and Yolk-Sac Diameter of Larvae of Eleotris acanthopoma and E. fusca

\begin{tabular}{|c|c|c|c|c|c|c|}
\hline & \multicolumn{2}{|c|}{ Notochord Length (mm) } & \multicolumn{2}{|c|}{ Total Length (mm) } & \multicolumn{2}{|c|}{ Yolk-Sac Diameter (mm) } \\
\hline & Range & Mean \pm SD & Range & Mean \pm SD & Range & Mean \pm SD \\
\hline \multicolumn{7}{|l|}{ E. acanthopoma } \\
\hline Newly hatched & $1.26-1.35$ & $1.31 \pm 0.03$ & $1.32-1.40$ & $1.36 \pm 0.03$ & $0.31-0.37$ & $0.35 \pm 0.02$ \\
\hline 1 day after hatching & $1.58-1.77$ & $1.69 \pm 0.06$ & $1.68-1.86$ & $1.77 \pm 0.06$ & $0.15-0.18$ & $0.17 \pm 0.01$ \\
\hline 2 days after hatching & $1.73-1.83$ & $1.79 \pm 0.03$ & $1.86-1.91$ & $1.89 \pm 0.02$ & $0.09-0.11$ & $0.10 \pm 0.01$ \\
\hline 3 days after hatching & $1.79-1.88$ & $1.84 \pm 0.03$ & $1.89-1.98$ & $1.95 \pm 0.03$ & $0.03-0.05$ & $0.04 \pm 0.01$ \\
\hline $\begin{array}{l}4 \text { days after hatching } \\
\text { E. fusca }\end{array}$ & $1.70-1.88$ & $1.79 \pm 0.06$ & $1.80-1.95$ & $1.89 \pm 0.06$ & 0 & 0 \\
\hline Newly hatched & $1.02-1.09$ & $1.05 \pm 0.02$ & $1.07-1.13$ & $1.10 \pm 0.02$ & $0.26-0.29$ & $0.27 \pm 0.01$ \\
\hline 1 day after hatching & $1.70-1.76$ & $1.72 \pm 0.02$ & $1.81-1.86$ & $1.82 \pm 0.02$ & $0.19-0.21$ & $0.20 \pm 0.01$ \\
\hline 2 days after hatching & $1.71-1.83$ & $1.75 \pm 0.04$ & $1.81-1.96$ & $1.87 \pm 0.04$ & $0.09-0.10$ & $0.10 \pm 0.00$ \\
\hline 3 days after hatching & $1.71-1.84$ & $1.79 \pm 0.04$ & $1.85-1.96$ & $1.91 \pm 0.03$ & $0.04-0.06$ & $0.05 \pm 0.01$ \\
\hline 4 days after hatching & $1.68-1.95$ & $1.76 \pm 0.07$ & $1.83-2.08$ & $1.90 \pm 0.07$ & 0 & 0 \\
\hline
\end{tabular}

Note: Measurements were collected daily immediately after hatching to the completion of larval yolk consumption under rearing conditions in the laboratory.

als, this characteristic could not be used to distinguish the species.

Two days after hatching (Figure $8 A-c, B-$ $c$ ), the larvae of $E$. acanthopoma were somewhat larger than they were the previous day $(1.73-1.83 \mathrm{~mm} \mathrm{NL})$, but the increase in size of E. fusca larvae was not detectable (1.71$1.83 \mathrm{~mm} \mathrm{NL}$ [Table 2]). The yolk sac of both species was further reduced, and the mouth and the pectoral fins began to form. A pair of free neuromasts connected to the notochord appeared within the finfold above the midtrunk. The ventral melanophores on the trunk and the tail became enlarged and some specimens of both species also had melanophores at the tip of the lower jaw, below the eyes, and ventrally on the posterior region of the gut. The irises of E. acanthopoma larvae were palely pigmented.

Three days after hatching (Figure $8 A-d, B-$ $d)$, the size of larvae of both species was similar to that of the previous day (Table 2). Remnants of the yolk sac were apparent, the mouth opened, and a gas bladder appeared above the gut. The eyes were fully pigmented and directed down-forward. Pigmentation increased, with melanophores occurring at the tip of the lower jaw, below the eyes, ventrally on the yolk sac, ventrally on the gut, ventrally on the trunk extending to above the anus, ventrally and dorsally on the midtail, and ventrally on the tip of the tail. Xanthophores occurred behind the eyes and around the ventral melanophores on the trunk and the midtail.

Four days after hatching (Figure $8 A-e, B-$ $e)$, the yolk sac in both species had disappeared.

\section{DISCUSSION}

The GSI measurements and morphology of the genital papilla indicated that most Eleotris acanthopoma matured at approximately $28 \mathrm{~mm}$ SL, whereas E. fusca usually matured at approximately $50 \mathrm{~mm}$ SL. Size at maturity for males and females in each species was similar. The smallest adults of both species appeared to be considerably smaller than the largest adults $(115 \mathrm{~mm}$ SL for E. acanthopoma and $151 \mathrm{~mm}$ SL for E. fusca in this study). However, data obtained in the field indicated that small mature males (30-40 mm SL) of $E$. acanthopoma cared for small egg masses (e.g., clutch size 1,500 [Table 1]). On the assumption that small egg masses were spawned by small females, we inferred that females also begin spawning soon after reaching sexual maturity at approximately $28 \mathrm{~mm}$ SL.

We could not determine whether the 
developed oocytes in the larger size class observed within the ovaries were spawned in one spawning event as a single clutch. We assumed that the oocytes would either be spawned at one or at several consecutive spawning events. Clutch sizes observed in the field (1,500-63,500 for E. acanthopoma, 33,600 for $E$. fusca) were smaller than number of developed oocytes within an ovary (600263,600 for E. acanthopoma; 2,200-398,200 for E. fusca). However, this might simply be attributed to our inability to locate larger egg masses in the field. We therefore assumed that larger egg masses were spawned by larger females, that they were cared for by larger males, and that they were likely to be deposited on the underside of large immovable rocks or in gaps in the bedrock where it would be difficult to find them. Matsuo and Takahama (2001) reported for Eleotris oxycephala that a female (137 mm SL) spawned 37,800 eggs $\left(210 \mathrm{~cm}^{2}\right)$ and another female (111 mm SL) spawned 178,000 eggs (810 $\mathrm{cm}^{2}$ ) as single clutches both under captive conditions. The egg morphology and eggmass form of Eleotris oxycephala (Dôtu and Fujita 1959, Dotsu et al. 2004) do not differ from that of the two species observed in our study. These observations suggest that $E$. acanthopoma and E. fusca may also be capable of spawning nearly 200,000 eggs in a single clutch, and that their clutch sizes may vary markedly between spawning events. It has been suggested that Eleotris acanthopoma spawns several times during the spawning season (Wang et al. 2001), and the oocyte diameter composition of the ovaries examined in our study supports the assumption that, as with most gobioid fishes (Miller 1984), $E$. acanthopoma and E. fusca are iteroparous. Frequency of spawning, life span, and age at first reproduction are also unknown, and this information is required to estimate lifetime fecundity.

Egg masses of E. acanthopoma were found in both brackish and freshwater areas, but those of $E$. fusca were found only in freshwater. Egg mass distribution was correlated with adult habitat preferences, which suggests that these species spawn in their usual habitats without undertaking any spawning migration.
This assumption is corroborated by the relative stability in adult distributions observed throughout the year (Maeda and Tachihara 2004). In the brackish-water areas, the environments surrounding the spawning sites of E. acanthopoma change with tide. For example, at one spawning site in the brackishwater area of Teima Stream where numerous egg masses were found during our study, salinities fluctuated between 0 and $32 \mathrm{ppt}$ with the tide (station 3 in Maeda and Tachihara 2004)

The egg masses of E. acanthopoma and $E$. fusca used for the description of early development may have begun hatching within 5 $\mathrm{hr}$ after collection while being transported to the laboratory; another egg mass of $E$. fusca (not used for description of development) was collected from Yona Stream at 1900 hours on 12 June 2004 and transferred to the laboratory, where it was maintained at $23^{\circ} \mathrm{C}$, and fish began hatching at 1930 hours the next day (i.e., embryos spent more than $24 \mathrm{hr}$ in their egg; hatched larvae were $1.11 \pm 0.05$ $\mathrm{mm}$ NL). Eleotris oxycephala has been reported to hatch 10-12 hr after spawning under captive conditions (Matsuo and Takahama 2001, Dotsu et al. 2004). Even though the time that embryos of $E$. acanthopoma spend in the egg may be relatively short, the eggs of E. acanthopoma deposited in brackishwater areas experience both low and high tide and develop under marked fluctuations in salinity.

The eggs of both species were deposited on the underside of submerged objects and were cared for by the male. This behavior is common among gobioid fish (Miller 1984, Kinzie 1997, Keith 2003), but the sparse arrangement of tiny eggs is a unique characteristic. An egg mass containing sparsely distributed eggs deposited within a bamboo tube has been observed in E. oxycephala (Dôtu and Fujita 1959), suggesting that such a sparse arrangement of eggs might be common within the genus. Although some sympatric gobiid fish also deposit similar tiny eggs on the underside of objects in streams on Okinawa Island, the sparse arrangement of eggs in Eleotris may help to distinguish between Eleotris egg masses and those of other 
species, even if parental fish cannot be observed; eggs of Sicyopterus japonicus are deposited in clusters, whereas eggs of Stiphodon percnopterygionus, Awaous melanocephalus, and Stenogobius sp. are deposited in single, dense layers (Dôtu and Mito 1955, Yamasaki and Tachihara 2007; our unpubl. data). However, the egg masses of E. acanthopoma and E. fusca could not be distinguished from each other in the absence of the parent.

Eggs and newly hatched larvae of E. acanthopoma and E. fusca are very small at $0.4 \mathrm{~mm}$ and $1.0-1.4 \mathrm{~mm} \mathrm{NL}$, respectively, and larvae exhibit an undeveloped stage that is characterized by a lack of pigmented eyes, mouth, and pectoral fins. Most newly hatched drifting larvae of amphidromous fish always occurred from dusk to midnight, peaking just after nightfall around their spawning sites in the streams on Okinawa Island (our unpubl. data) and elsewhere (Iguchi and Mizuno 1990, Tomiyama et al. 1999, Luton et al. 2005), indicating that they naturally hatch in the evening. It was possible that hatching was provoked by the disturbance caused by collection and handling of the eggs in our study, but the size and developmental stage of the newly hatched larvae observed in the evening were similar to those of drifting Eleotris larvae found in streams on Okinawa Island (0.9-1.3 $\mathrm{mm}$ NL [our unpubl. data]). The eggs and newly hatched larvae of all Eleotris species described to date have exhibited small size and similar morphologies, although such data have only been readily available for E. oxycephala (Dôtu and Fujita 1959, Dotsu et al. 2004) and Eleotris sandwicensis (Lindstrom 1999). In addition, the mean diameter of ripe oocytes in E. aquadulcis has been reported as being $0.27 \mathrm{~mm}$ (Allen and Coates 1990), suggesting that that species may also spawn similarly small eggs. Several other eleotrid fishes (Hypseleotris spp., Ophieleotris aporos, and Dormitator latifrons) and sicydiine gobies and their relatives (Sicyopterus spp., Sicydium punctatum, Stiphodon percnopterygionus, Lentipes concolor, Awaous spp., and Stenogobius hawaiiensis) have been reported to exhibit a similar trend toward small eggs and larvae (Manacop 1953, Dôtu and Mito 1955, Lake 1967, Anderson et al. 1971, Todd 1975,
Maciolek 1977, Auty 1978, Coates 1992, Kinzie 1993, 1997, Bell and Brown 1995, Ha and Kinzie 1996, Dotsu et al. 1998, 2000, Lindstrom 1999, Yamasaki and Tachihara 2006, 2007). These fishes are also highly fecund, which has been demonstrated to be inversely related to egg size (Miller 1984). Egg size in these species, including Eleotris, is considerably smaller than that of certain amphidromous gobioids, such as Gobiomorphus buttoni from New Zealand $(0.8 \mathrm{~mm}$ [McDowall 1965]), and Tridentiger kuroiwae (1.2 mm [unpubl. data]) and Rhinogobius spp. (2.2-2.8 mm [unpubl. data]) on Okinawa Island, suggesting that amphidromous gobioids do not always have very small eggs and larvae.

The reproductive strategy of $E$. acanthopoma and E. fusca is characterized by high fecundity, small eggs, and small newly hatched larvae; these characteristics are shared with several of the eleotrid fishes and sicydiine gobies mentioned previously. The typical habitat dominated by gobioid fish with this reproductive strategy is known to be tropical and subtropical insular streams (Ryan 1991, Nelson et al. 1997, Fitzsimons et al. 2002, Keith et al. 2006). But some species have succeeded in other habitats. For example, Hypseleotris compressa and Hypseleotris klunzingeri dominate a variety of habitats in Australian rivers (Pusey et al. 2004), and E. oxycephala is distributed in the lower reaches of rivers in temperate Japan (Akihito et al. 2002). It is interesting that $H$. klunzingeri even completes its entire life cycle in freshwater (Pusey et al. 2004). Coates (1992) suggested that the high reproductive capacity of $O$. aporos in Papua New Guinea may be an adaptation to floodplain habitats and the high predation pressure on their adults by Oxyeleotris heterodon.

Although this reproductive strategy may be favorable in a variety of habitats, we specifically discuss the possibility of widespread larval dispersal arising from this reproductive strategy. The duration of the pelagic larval stage of E. acanthopoma and E. fusca was relatively longer than in typical coastal marine gobies and some amphidromous gobies, and recruitment into Okinawan streams was suggested to include exogenous larvae (Maeda et al. 2007). Records of unusual eleotrid fish and 
sicydiine goby species, which are not commonly found in the Ryukyu Archipelago (e.g., Yonezawa and Iwata 2001, Maeda and Tachihara 2006), Shikoku, and Honshu (e.g., Shibuya and Takahashi 1998, Hirashima and Nakatani 2006), also suggest the existence of exogenous recruitment via the Kuroshio Current. Widespread distributions of Eleotris spp. and sicydiine gobies among many oceanic islands may be facilitated by widespread dispersal during the pelagic larval stage. Such dispersal events are thought to be advantageous on small islands in tropical and subtropical regions where small unstable streams are sparsely distributed. Widespread larval dispersal would be required to ensure continued survival of the species because life cycles that restrict species to such limited areas would increase the risk of extinction of locally adapted populations in the event of widespread habitat loss. The tradeoff to this dispersal strategy is that a considerable proportion of larvae are likely to be lost because they may not reach streams that are suitable for successful recruitment. The increased fecundity described in this study may thus contribute to an increased likelihood of successful recruitment in suitable habitat and to a reduction in the risks associated with widespread dispersal.

\section{ACKNOWLEDGMENTS}

We express our appreciation to two reviewers for their helpful comments. We are grateful to the members of the Laboratory of Fisheries Biology and Coral Reef Studies, University of the Ryukyus, who supported our surveys.

\section{Literature Cited}

Akihito, K. Sakamoto, Y. Ikeda, and K. Sugiyama. 2002. Gobioidei. Pages 11391310 in T. Nakabo, ed. Fishes of Japan with pictorial keys to the species, English ed. Tokai University Press, Tokyo.

Allen, G. R., and D. Coates. 1990. An ichthyological survey of the Sepik River, $\mathrm{Pa}$ pua New Guinea. Rec. West. Aust. Mus. Suppl. 34:31-116.
Anderson, J. R., J. S. Lake, and N. J. Mackay. 1971. Notes on reproductive behaviour and ontogeny in two species of Hypseleotris (= Carassiops) (Gobiidae: Teleostei). Aust. J. Mar. Freshwater Res. 22:139-145.

Auty, E. H. 1978. Reproductive behaviour and early development of the empire fish Hypseleotris compressus (Eleotridae). Aust. J. Mar. Freshwater Res. 29:585-597.

Bell, K. N. I., and J. A. Brown. 1995. Active salinity choice and enhanced swimming endurance in 0 to 8 -d-old larvae of diadromous gobies, including Sicydium punctatum (Pisces), in Dominica, West Indies. Mar. Biol. (Berl.) 121:409-417.

Chubb, A. L., R. M. Zink, and J. M. Fitzsimons. 1998. Patterns of mtDNA variation in Hawaiian freshwater fishes: The phylogeographic consequences of amphidromy. J. Hered. 89:8-16.

Coates, D. 1992. Biology of Oxyeleotris heterodon and its major prey, Ophieleotris aporos, two floodplain sleepers (Pisces: Eleotrididae) of the Sepik River fishery, northern Papua New Guinea. Environ. Biol. Fishes 34:51-64.

Dotsu, Y., K. Miyaki, T. Matsuo, Y. Ono, and H. Takahama. 2004. Induced spawning, larval rearing and development of the sleeper, Eleotris oxycephala Temmink et Schlegel, gobioid fish. Bull. Fac. Fish. Nagasaki Univ. 85:1-8 [in Japanese with English abstract].

Dotsu, Y., T. Suzuki, and M. Yanagi. 1998. Spawning-induction, embryonic development and larvae of the carp-like sleeper Hypseleotris cyprinoides, gobiid fish. Trans. Nagasaki Biol. Soc. 49:15-21 [in Japanese with English abstract].

Dotsu, Y., M. Yanagi, and T. Inui. 2000. Spawning-induction and larva-rearing of the Australian gobiid fish Hypseleotris compressus. Bull. Fac. Fish. Nagasaki Univ. 81:43-48 [in Japanese with English abstract].

Dôtu, Y., and S. Fujita. 1959. The bionomics and life history of the eleotrid fish, Eleotris oxycephala Temmink et Schlegel. Bull. Fac. Fish. Nagasaki Univ. 8:191-195 + 1 pl. [in Japanese with English abstract].

Dôtu, Y., and S. Mito. 1955. Life history of a 
gobioid fish, Sicydium japonicum Tanaka. Sci. Bull. Fac. Agric. Kyushu Univ. 15:213-221 [in Japanese with English abstract].

Fitzsimons, J. M., J. E. Parham, and R. T. Nishimoto. 2002. Similarities in behavioral ecology among amphidromous and catadromous fishes on the oceanic islands of Hawai' $i$ and Guam. Environ. Biol. Fishes 65:123-129.

Fitzsimons, J. M., R. M. Zink, and R. T. Nishimoto. 1990. Genetic variation in the Hawaiian stream goby, Lentipes concolor. Biochem. Syst. Ecol. 18:81-83.

Ha, P. Y., and R. A. Kinzie III. 1996. Reproductive biology of Awaous guamensis, an amphidromous Hawaiian goby. Environ. Biol. Fishes 45:383-396.

Hirashima, K., and Y. Nakatani. 2006. Record of Ophieleotris sp.1 (Pisces, Gobioidei) from the Kii Peninsula, Japan. NankiSeibutsu 48:67-68 [in Japanese].

Iguchi, K., and N. Mizuno. 1990. Diel changes of larval drift among amphidromous gobies in Japan, especially Rhinogobius brunneus. J. Fish Biol. 37:255-264.

Keith, P. 2003. Biology and ecology of amphidromous Gobiidae of the Indo-Pacific and the Caribbean regions. J. Fish Biol. 63:831-847.

Keith, P., T. Galewski, G. Cattaneo-Berrebi, T. Hoareau, and P. Berrebi. 2005. Ubiquity of Sicyopterus lagocephalus (Teleostei: Gobioidei) and phylogeography of the genus Sicyopterus in the Indo-Pacific area inferred from mitochondrial cytochrome $b$ gene. Mol. Phylogenet. Evol. 37:721732.

Keith, P., C. Lord, and E. Vigneux. 2006. In vivo observations on postlarval development of freshwater gobies and eleotrids from French Polynesia and New Caledonia. Ichthyol. Explor. Freshwaters 17:187-191.

Kinzie, R. A., III. 1993. Reproductive biology of an endemic, amphidromous goby Lentipes concolor in Hawaiian streams. Environ. Biol. Fishes 37:257-268.

. 1997. Evolution and life history patterns in freshwater gobies. Micronesica 30:27-40.
Lake, J. S. 1967. Rearing experiments with five species of Australian freshwater fishes, II. Morphogenesis and ontogeny. Aust. J. Mar. Freshwater Res. 18:155-173.

Lindstrom, D. P. 1999. Molecular species identification of newly hatched Hawaiian amphidromous gobioid larvae. Mar. Biotechnol. 1:167-174.

Luton, C. D., A. M. D. Brasher, D. C. Durkin, and P. Little. 2005. Larval drift of amphidromous shrimp and gobies on the island of Oahu, Hawai'i. Micronesica 38:1-16.

Maciolek, J. A. 1977. Taxonomic status, biology, and distribution of Hawaiian Lentipes, a diadromous goby. Pac. Sci. 31:355-362.

Maeda, K., and K. Tachihara. 2004. Instream distributions and feeding habits of two species of sleeper, Eleotris acanthopoma and Eleotris fusca in the Teima River, Okinawa Island. Ichthyol. Res. 51:233-240.

- 2005. Recruitment of amphidromous sleepers Eleotris acanthopoma, Eleotris melanosoma and Eleotris fusca into the Teima River, Okinawa Island. Ichthyol. Res. 52:325-335.

- 2006. Fish fauna in the Teima Stream, Okinawa Island. Biol. Mag. Okinawa 44:7-25 [in Japanese with English abstract].

Maeda, K., N. Yamasaki, and K. Tachihara. 2007. Size and age at recruitment and spawning season of sleeper, genus Eleotris (Teleostei: Eleotridae) on Okinawa Island, southern Japan. Raffles Bull. Zool. Suppl. 14:199-207.

Manacop, P. R. 1953. The life history and habits of the goby, Sicyopterus extraneus Herre (anga) Gobiidae with an account of the goby-fry fishery of Cagayan River, Oriental Misamis. Philipp. J. Fish. 2:160.

Marquet, G., and R. Galzin. 1992. Systématique, répartition et biomasse des poissons d'eau douce de Polynésie française. Cybium 16:245-259.

Matsuo, T., and H. Takahama. 2001. Courtship and spawning behavior of Eleotris oxycephala in an aquarium. Jpn. J. Ichthyol. 48:53-57 [in Japanese with English abstract]. 
McDowall, R. M. 1965. Studies on the biology of the red-finned bully Gobiomorphus buttoni (Ogilby), II.-breeding and life history. Trans. R. Soc. N. Z. Zool. 5:177196.

Miller, P. J. 1984. The tokology of gobioid fishes. Pages 119-152 in G. W. Potts and R. J. Wooton, eds. Fish reproduction: Strategies and tactics. Academic Press, London.

Nelson, S. G., J. E. Parham, R. B. Tibbatts, F. A. Camacho, T. Leberer, and B. D. Smith. 1997. Distributions and microhabitats of the amphidromous gobies in streams of Micronesia. Micronesica 30:83-91.

Pezold, F., and B. Cage. 2002. A review of the spinycheek sleepers, genus Eleotris (Teleostei: Eleotridae), of the Western Hemisphere, with comparison to the West African species. Tulane Stud. Zool. Bot. 31:19-63.

Pusey, B., M. Kennard, and A. Arthington. 2004. Freshwater fishes of north-eastern Australia. CSIRO Publishing, Collingwood, Victoria, Australia.

Ryan, P. A. 1991. The success of the Gobiidae in tropical Pacific streams. N. Z. J. Zool. 18:25-30.

Shibuya, M., and H. Takahashi. 1998. Stiphodon sp. collected from Kochi Prefecture. I. O. P. Diving News 10 (1): 5 [in Japanese].

Todd, E. S. 1975. Vertical movements and development of the prolarvae of the eleotrid fish, Dormitator latifrons. Copeia 1975:564-568.

Tomiyama, T., H. Honda, A. Okata, and M.
Omori. 1999. Larval drift patterns of diadromous gobioids in the lower course of the Natori River, northern Japan. Tohoku J. Agric. Res. 50:11-21.

Wang, H.-Y., C.-F. Weng, M.-C. Tu, and S.-C. Lee. 2001. Synchronization of plasma steroid concentrations and gonadal cycles in the sleeper, Eleotris acanthopoma. Zool. Stud. 40:14-20.

Watanabe, S., M. Iida, Y. Kimura, E. Feunteun, and K. Tsukamoto. 2006. Genetic diversity of Sicyopterus japonicus as revealed by mitochondrial DNA sequencing. Coastal Mar. Sci. 30:473-479.

Yamamoto, M. N., and A. W. Tagawa. 2000. Hawai'i's native and exotic freshwater animals. Mutual Publishing, Honolulu.

Yamasaki, N., and K. Tachihara. 2006. Reproductive biology and morphology of eggs and larvae of Stiphodon percnopterygionus (Gobiidae: Sicydiinae) collected from Okinawa Island. Ichthyol. Res. 53:12-18.

- 2007. Eggs and larvae of Awaous melanocephalus (Teleostei: Gobiidae). Ichthyol. Res. 54:89-91.

Yonezawa, T., and A. Iwata. 2001. First record of a gobiid fish Stiphodon surrufus from Yakushima Island, Japan. I. O. P. Diving News 12 (9): 2-4 [in Japanese with English abstract].

Zink, R. M., J. M. Fitzsimons, D. L. Dittmann, D. R. Reynolds, and R. T. Nishimoto. 1996. Evolutionary genetics of Hawaiian freshwater fish. Copeia 1996:330-335. 